\title{
АНАЛІЗ РЕЗУЛЬТАТІВ АНКЕТУВАННЯ СТУДЕНТІВ ВИЩИХ МЕДИЧНИХ НАВЧАЛЬНИХ ЗАКЛАДІВ 3 ПИТАНЬ ДЕРЖАВНОЇ АТЕСТАЦЇ
}

\author{
О. П. Волосовець ${ }^{1}$, І. Є. Булах ${ }^{2}$, Л. П. Войтенко ${ }^{2}$

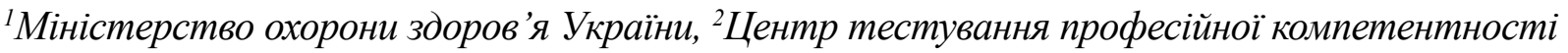 \\ фахівців з вищою освітою напрямів підготовки “Медицина” $i$ “Фармація” " при Міністерстві \\ охорони здоров'я Украӥни
}

\section{ANALYSIS OF THE RESULTS OF STUDENTS' POLLING OF HIGHER MEDICAL EDUCATIONAL INSTITUTIONS ON THE ISSUES OF THE STATE ATTESTATION}

\author{
O. P. Volosovets' ${ }^{1}$ I. Ye. Bulakh², L. P. Voytenko \\ ${ }^{1}$ Ministry of Public Health of Ukraine, \\ ${ }^{2}$ Center for testing of professional competence of specialists with higher education of training \\ directions "Medicine" and "Pharmacy" affiliated to the Ministry of Public Health of Ukraine
}

\begin{abstract}
У статті проаналізовано результати анкетування студентів вищих медичних навчальних закладів з питань державної атестації, що продемонстрували незалежну оцінку щодо якості підготовки з боку основних суб'єктів навчального процесу - студентів та лікарів-інтернів і засвідчили позитивний вплив системного моніторингу навчально-методичної діяльності ВМНЗ на організацію навчального процесу ВМНЗ.

The article analyzed the results of students' polling of higher medical educational institutions on the issues of the state attestation, that demonstrate the independent assessment regarding the quality of training from the main subjects of educational process - of students and doctors-interns and testity to the positive influence of system monitoring of educational methodical activity of HMEI for the organization of educational process of HMEI.
\end{abstract}

Вступ. Навчально-методичне забезпечення діяльності вищих медичних (фармацевтичного) навчальних закладів разом із іншими компонентами педагогічного процесу має утворювати науково-теоретичну й концептуальну єдність професійної підготовки спеціалістів для сфери охорони здоров’я. Саме тому питання поліпшення організації навчального процесу, якості теоретичної та практичної підготовки студентів, лікарів (провізорів)-інтернів та слухачів, упровадження позитивних результатів навчально-методичної діяльності вищих навчальних закладів традиційно належать до актуальних питань дидактики вищої школи та постійно перебувають у центрі уваги фахівців.

Так, на виконання наказу Міністерства охорони здоров’я України (далі - МО3 України) № 834 від 24.10.2012 р. "Про навчально-методичну діяльність вищих медичних та фармацевтичних навчальних закладів I - IV рівнів акредитації” та з метою здійснення системного моніторингу навчальнометодичної діяльності вищих медичних (фармацевтичного) навчальних закладів та закладів післядипломної освіти (далі - ВМ(Ф)НЗ) Міністерством охорони здоров'я України організовано роботу моніторингових груп у вищих навчальних закладах, що здійснюють підготовку спеціалістів для сфери охорони здоров'я.

Основна частина. Під час роботи моніторингових груп у ВМ(Ф)НЗ спільно з представниками студентського самоврядування проведено анкетування суб'єктів навчання щодо рівня їх практичної підготовки та стану навчально-методичної діяльності $\mathrm{BM}(Ф) Н З$. Для дослідження зазначених вище питань фахівцями МОЗ України, Центру тестування професійної компетентності фахівців з вищою освітою напрямів підготовки “Медицина” i “Фармація” при МО3 України та Центральним методичним кабінетом 3 вищої медичної освіти було розроблено анкету, яка складалась 3 трьох частин: вступної, основної та демографічної.

У вступній частині анкети представлена інформація про завдання та значення даного опитування, роль правдивості кожної відповіді, правила заповнення анкети. 
Основна частина анкети складалась із питань, покликаних вирішити завдання даного опитування: забезпеченість ВНЗ бібліотечним (книжковим та електронним) фондом, умови для підготовки до занять у гуртожитку ВН3, забезпеченість ВНЗ комп'ютерною та мультимедійною технікою, користування Webпорталом ВНЗ та ресурсами мережі Інтернет, підготовка до державної атестації, оцінка діяльності кафедр ВНЗ. Питання цієї частини умовно були поділені на три секції: “Інформація про Вас", "Науково-методичне забезпечення навчального процесу" та "Матеріальне забезпечення навчального процесу”.

В демографічній частині анкети з'ясовувалась інформація для якісного аналізу зібраного матеріалу та для визначення репрезентативності отриманих даних (курс, факультет, стать, вік, місце проживання під час навчання у ВНЗ тощо).
Після аналізу перших результатів анкетування, проведеного в Одеському національному медичному університеті, Тернопільському державному медичному університеті імені І. Я. Горбачевського та Львівському національному медичному університеті імені Данила Галицького,ї представлення та обговорення на нараді ректорів вищих медичних (фармацевтичного) навчальних закладів IV рівня акредитаціїтазакладів післядипломної освіти МОЗ України 15 січня 2013 року, анкету було доповнено ще двома секціями: "Інформаційно-освітнє середовище ВМ(Ф)НЗ” та “Підготовка до державної атестації'. Таким чином, анкета складалася 3 п’яти секцій, що містили запитання закритого та відкритого типів.

На сьогодні за допомогою групового анкетування проведено опитування 4377 студентів дев'яти $\mathrm{BM}(\Phi) Н 3$, оброблено та проаналізовано результати 3195 студентів семи ВМ(Ф)НЗ (табл. 1).

Таблиця 1. Контингент студентів, які взяли участь в анкетуванні з питань державної атестації

\begin{tabular}{|c|c|c|c|c|}
\hline ВМ(Ф)H3 & Курс & Факультет & Кількість студентів & Всього \\
\hline \multirow{4}{*}{$\begin{array}{c}\text { Одеський національний } \\
\text { медичний університет } \\
\text { (ОНМУ) }\end{array}$} & 6 & медичний & 189 & \multirow{4}{*}{417} \\
\hline & 5 & $\begin{array}{l}\text { медичний } \\
\text { стоматологічний }\end{array}$ & 39 & \\
\hline & 4 & медичний & 89 & \\
\hline & \multicolumn{2}{|r|}{ інтернатура } & 100 & \\
\hline \multirow{4}{*}{$\begin{array}{c}\text { Тернопільський державний } \\
\text { медичний університет імені } \\
\text { І. Я. Горбачевського } \\
\text { (ТДМУ) }\end{array}$} & 6 & медичний & 68 & \multirow{4}{*}{365} \\
\hline & 5 & $\begin{array}{l}\text { медичний } \\
\text { стоматологічний }\end{array}$ & 63 & \\
\hline & 3 & $\begin{array}{l}\text { медичний } \\
\text { стоматологічний } \\
\text { фармацевтичний } \\
\end{array}$ & 122 & \\
\hline & \multicolumn{2}{|r|}{ інтернатура } & 112 & \\
\hline \multirow{4}{*}{$\begin{array}{c}\text { Львівський національний } \\
\text { медичний університет } \\
\text { імені Данила Галицького } \\
\text { (ЛвНМУ) }\end{array}$} & 6 & медичний & 61 & \multirow{4}{*}{476} \\
\hline & 5 & фармацевтичний & 78 & \\
\hline & 3 & медичний & 231 & \\
\hline & \multicolumn{2}{|r|}{ інтернатура } & 106 & \\
\hline \multirow{4}{*}{$\begin{array}{c}\text { Донецький національний } \\
\text { медичний університет } \\
\text { імені М. Горького } \\
\text { (ДНМУ) }\end{array}$} & 6 & медичний & 100 & \multirow{4}{*}{498} \\
\hline & 5 & $\begin{array}{l}\text { медичний } \\
\text { стоматологічний }\end{array}$ & 149 & \\
\hline & 4 & медичний & 100 & \\
\hline & \multicolumn{2}{|r|}{ інтернатура } & 149 & \\
\hline \multirow{4}{*}{$\begin{array}{c}\text { Луганський національний } \\
\text { медичний університет } \\
\text { (ЛугНМУ) }\end{array}$} & 6 & медичний & 156 & \multirow{4}{*}{444} \\
\hline & 5 & $\begin{array}{l}\text { медичний } \\
\text { стоматологічний }\end{array}$ & 49 & \\
\hline & 4 & медичний & 110 & \\
\hline & & інтернатура & 125 & \\
\hline \multirow{4}{*}{$\begin{array}{c}\text { Запорізький державний } \\
\text { медичний університет } \\
\text { (ЗДМУ) }\end{array}$} & 6 & медичний & 155 & \multirow{4}{*}{550} \\
\hline & 5 & $\begin{array}{l}\text { стоматологічний } \\
\text { фармацевтичний }\end{array}$ & 140 & \\
\hline & 4 & медичний & 150 & \\
\hline & & інтернатура & 105 & \\
\hline \multirow{4}{*}{$\begin{array}{c}\text { Державний заклад } \\
\text { “Дніпропетровська медична } \\
\text { академія” (ДМА) }\end{array}$} & 6 & медичний & 68 & \multirow{4}{*}{445} \\
\hline & 5 & стоматологічний & 109 & \\
\hline & 4 & медичний & 166 & \\
\hline & & інтернатура & 102 & \\
\hline
\end{tabular}


Зупинимося детальніше на аналізі відповідей студентів та лікарів-інтернів на питання секції "Підготовка до державної атестації”.

Відповідно до Положення про організацію та порядок проведення державної атестації студентів, які навчаються у вищих навчальних закладах III - IV рівнів акредитації за напрямом підготовки "Медицина" державна атестація випускників вищих медичних навчальних закладів проводиться у формі стандартизованого тестового державного іспиту “Крок”, який вимірює рівень професійної компетентності фахівця, та практично-орієнтованого державного іспиту, яким оцінюється здатність випускника вирішувати типові задачі діяльності лікаря в умовах, наближених до професійної діяльності.

Питання секції “Підготовка до державної атестації” передбачали здійснення оцінки студентами та лікарями-інтернами організації підготовки до складання ліцензійних інтегрованих іспитів “Крок” та практично-орієнтованого державного іспиту, місця формування та удосконалення практичних навичок, самооцінки рівня власних практичних навичок надання допомоги при невідкладних станах відповідно до списку 3 освітньо-кваліфікаційної характеристики спеціаліста за спеціальністю 7.110101 "Лікувальна справа" напряму підготовки "Медицина" Галузевих стандартів вищої освіти $[1,2]$.

Аналіз результатів анкетування на питання щодо оцінки організації підготовки до складання ліцензійних іспитів дозволяє стверджувати, що більшість студентів та лікарів-інтернів оцінили підготовку до складання ліцензійних інтегрованих іспитів "Крок" (далі - ЛІІ) як “добре” незалежно від курсу, на якому вони навчаються (рис. 1). Оцінювання здійснювалося за чотирибальною шкалою: дуже добре, добре, задовільно, незадовільно.

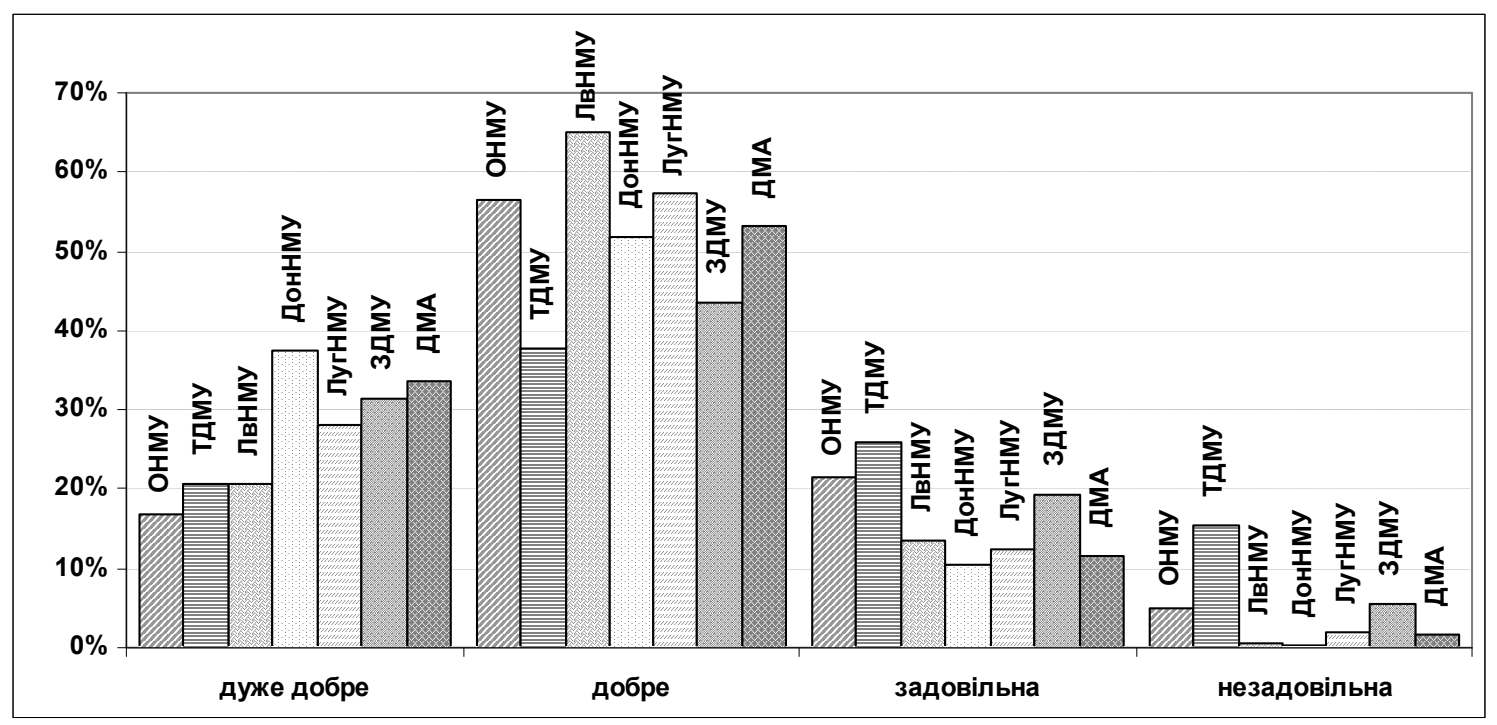

Puc. 1. Оцінка студентами та лікарями-інтернами ВМ(Ф)НЗ організації підготовки до складання ЛІІ "Крок".

Найбільший відсоток студентів та лікарів-інтернів оцінили організацію підготовки до складання ЛІІ як “дуже добре" у ДНМУ (37,6 \% опитаних), ДМА (33,6 \% опитаних), ЗДМУ (31,4 \% опитаних).

Найбільший відсоток студентів та лікарів-інтернів оцінили організацію підготовки до складання ЛІІ як “незадовільна" у ТДМУ (15,6 \% опитаних), ЗДМУ (5,5 \% опитаних) та ОНМУ. Разом з тим показник оцінки студентами та лікарями-інтернами підготовки до складання ЛІІ як “незадовільна” $€$ найменшим у ДНМУ ( $0,2 \%$ опитаних) та ЛвНМУ.

Аналіз результатів анкетування на поставлене питання у розрізі факультетів ВМ(Ф)НЗ показує, що більшість опитаних студентів та лікарів-інтернів ме- дичних факультетів оцінили підготовку до складання ЛІІ як “добре” незалежно від ВМ(Ф)НЗ, у якому вони навчаються; більшість студентів та лікарів-інтернів стоматологічних факультетів ВМ(Ф)НЗ оцінили підготовку до складання ЛІІ як “добре”. Виняток становлять студенти-стоматологи ДНМУ, більшість (62\%) студентів та лікарів-інтернів якого оцінили організацію підготовки до ЛІІ як “дуже добре”.

Подібною є оцінка студентами та лікарями-інтернами $\mathrm{BM}(\Phi) Н 3$ підготовки до складання практично-орієнтованого державного іспиту (далі - ПОДІ): більшість опитаних оцінили організацію підготовки як “добре” незалежно від ВМ(Ф)НЗ, факультету та курсу, на якому вони навчаються (рис. 2). Виняток ста- 


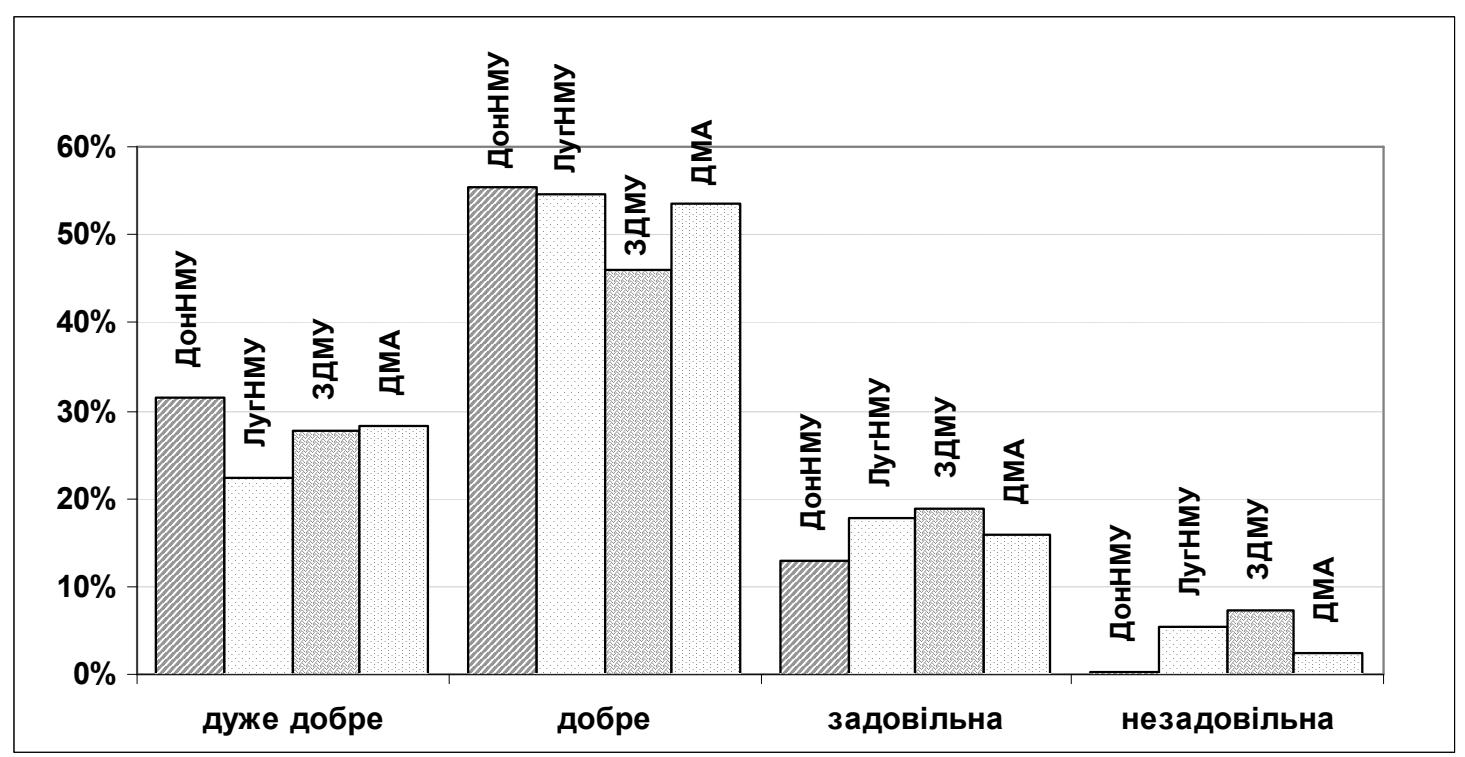

Puc. 2. Оцінка студентами та лікарями-інтернами ВМ(Ф)НЗ організації підготовки до складання практично-орієнтованого державного іспиту.

новлять опитані студенти та лікарі-інтерни стоматологічного факультету ДНМУ, більшість яких (50 \%) оцінили організацію до складання ПОДІ як “дуже добре". При цьому жоден із них не оцінив підготовку до складання ПОДІ як “незадовільна".

Показник оцінки студентами та лікарями-інтернами підготовки до складання ПОДІ як “незадовіль- на" є найменшим у ДНМУ (0,2 \% опитаних).

Аналіз результатів анкетування на питання щодо можливості формування та удосконалення студентами ВМ(Ф)НЗ практичних навичок показав, що понад $90 \%$ опитаних студентів 6 курсу медичних факультетів здобувають практичні навички біля ліжка хворого (рис. 3).

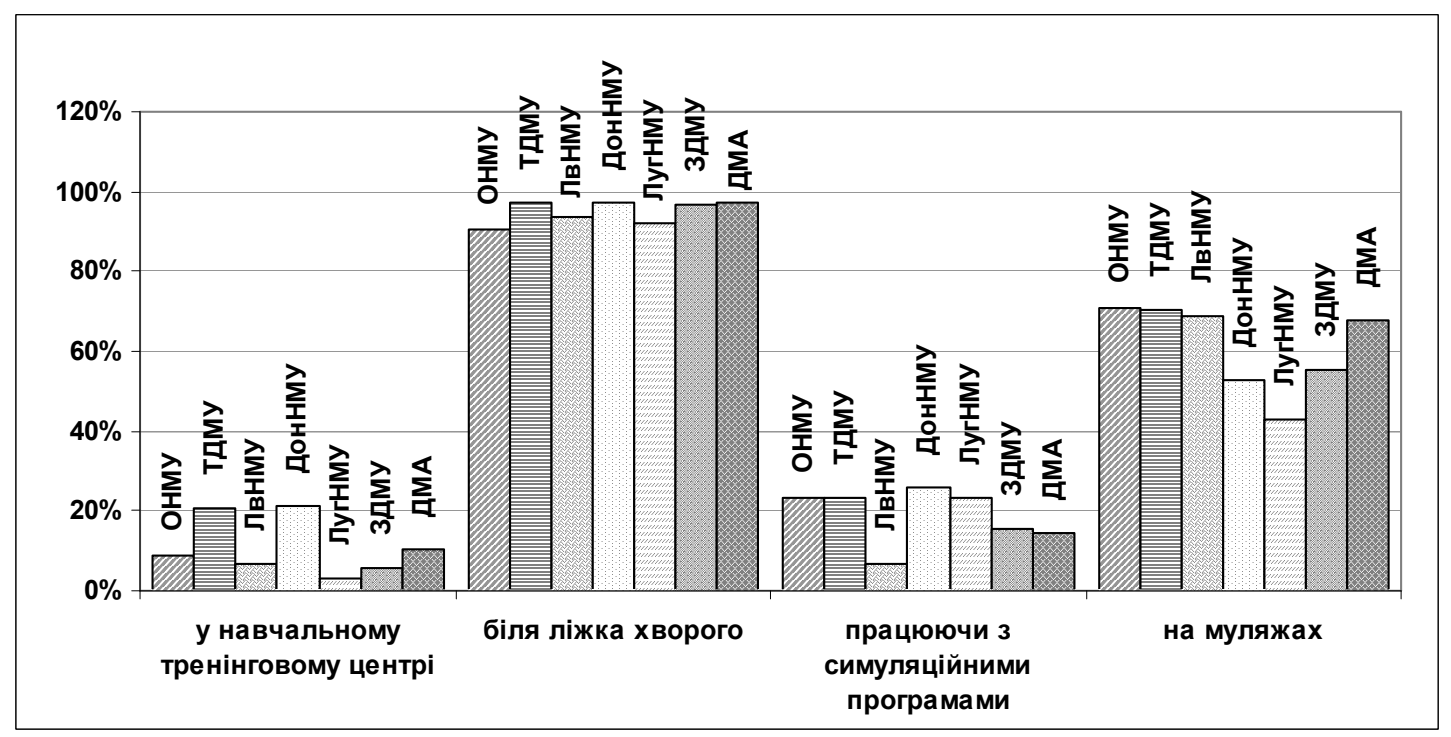

$\boldsymbol{P u c . ~ 3 . ~ М і с ц е ~ ф о р м у в а н н я ~ т а ~ у д о с к о н а л е н н я ~ п р а к т и ч н и х ~ н а в и ч о к ~ с т у д е н т а м и ~} 6$ курсу медичних факультетів $\mathrm{BM}(\Phi) \mathrm{H} 3$.

За результатами анкетування можна стверджувати, що всі ВМ $(\Phi) Н 3$, які відвідала моніторингова група, в достатній мірі обладнані муляжами. Найбільшим показник використання муляжів у практичній підготовці лікарів спостерігається у ОНМУ (вказали 70,9 \% опитаних) та ТДМУ (вказали 70,6 \% опитаних).
Аналіз результатів анкетування дозволяє виявити потребу в інтенсифікації впровадження у навчальний процес ВМ(Ф)НЗ, у тому числі й у практичну підготовку студентів, симуляційних програм та навчально-тренінгових центрів практичної підготовки.

Привертають увагу дані, що відображають само- 
оцінку лікарями-інтернами з надання допомоги при невідкладних станах. Оцінка здійснювалася за чотирибальною шкалою: дуже добре, добре, задовільно, незадовільно.

Більшість лікарів-інтернів незалежно від ВМ(Ф)НЗ, у якому вони навчаються, оцінили як “дуже добре” власні навички з надання допомоги при таких чотиpьox невідкладних станах, як: гіпертонічний криз, зовнішні кровотечі, непритомність та тепловий удар.

Разом 3 тим, оволодіння такими n'ятьма невідкладними станами, як гостра надниркова, гостра печінкова недостатність та гострі радіаційні ураження, лікарі-інтерни незалежно від ВМ(Ф)Н3, у якому вони навчаються, оцінили як “задовільно”.

Викладене вище дозволяє констатувати не-

\section{Лiтература}

1. Галузевий стандарт вищої освіти. Освітньо-кваліфікаційна характеристика спеціаліста за спеціальністю 7.110101 “Лікувальна справа” напряму підготовки 1101 “Медицина”; Введ.16.04.03. -К. : Книга-плюс, 2003. - 25 с. обхідність поліпшення практичної підготовки лікарів з зазначених вище п'яти невідкладних станів.

Необхідно також зауважити, що оволодіння такими трьома невідкладними станами, як непритомність, переохолодження та тепловий удар, жоден iз лікарів-інтернів ВМ(Ф)НЗ не оцінили як “незадовільно".

Висновок. Системний моніторинг навчально-методичної діяльності вищих медичних навчальних закладів, розпочатий у 2012 році, як засіб порівнювальності, засвідчив його позитивний вплив на організацію навчального процесу ВМНЗ. Результати анкетування продемонстрували незалежну оцінку щодо якості підготовки з боку основних суб'єктів навчального процесу - студентів та лікарів-інтернів.

2. Галузевий стандарт вищої освіти. Освітньо-професійна програма підготовки спеціаліста за спеціальністю 7.110101 “Лікувальна справа" напряму підготовки 1101 “Медицина”; Введ.16.04.03.-К. : Книга-плюс, 2003. - 116 с. 